\title{
Applications and Benefits of Catalytic Converter Thermal Management
}

\author{
Steven D. Burch, Matthew A. Keyser, Chris P. Colucci, \\ Thomas F. Potter, David K. Benson \\ National Renewable Energy Laboratory
}

John P. Biel

Benteler Industries, Inc.

\section{ABSTRACT}

A catalytic converter thermal management system (TMS) using variable-conductance vacuum insulation and phase-change thermal storage can maintain the converter temperature above its operating temperature for many hours, allowing most trips to begin with minimal "cold-start" emissions. The latest converter TMS prototype was tested on a Ford Taurus (3.0 liter flex-fuel engine) at Southwest Research Institute. Following a 24-hour soak, the FTP-75 emissions were $0.031,0.13$, and $0.066 \mathrm{~g} / \mathrm{mile}$ for $\mathrm{NMHC}, \mathrm{CO}$, and $\mathrm{NO}$, respectively. Tests were also run using $85 \%$ ethanol (E85), resulting in values of $0.005,0.124$, and 0.044 $\mathrm{g} / \mathrm{mile}$, and $0.005 \mathrm{~g} / \mathrm{mile}$ NMOG. Compared to the baseline FTP levels, these values represent reductions of $84 \%$ to $96 \%$ for NMHC, NMOG, and CO.

\section{BACKGROUND}

Mobile sources (primarily automobiles) produce $66 \%$ of the total US toxic gas carbon monoxide (CO), $38 \%$ of non-methane hydrocarbon (NMHC) gases and $44 \%$ of oxides of nitrogen (NOx) (contributors to smog) [Graedel, 1988]. Automobile emissions of these pollutants have decreased dramatically over the past 30 years (>95\% for NMHC, on a grams-per-mile basis). However, as the number of vehicle miles traveled per year continues to increase, automakers face increasingly stringent state and federal regulations. California's ULEV (Ultra-Low Emission Vehicle) standard, which starts its phase-in during 1998, is generally viewed as the toughest to meet. It requires vehicles to produce no more than 0.040 grams of reactivity-adjusted non-methane organic compounds (NMOG) using the 1975 Federal Test Procedure (FTP75). NMOG is similar to NMHC, but accounts for carbonyls and alcohols as well as the atmospheric reactivity of each hydrocarbon.
Today's engines use computer-controlled fuelinjection systems to minimize emission production. In addition, three-way catalytic converters are used to treat engine-out emissions. Converters are up to $97 \%$ effective at converting $\mathrm{CO}$ and $\mathrm{NMHC}$ to carbon dioxide and water vapor. However, to achieve these high conversion rates, the converters must be hot, typically about $300 \mathrm{C}$ or greater. More than half $(60 \%$ to $80 \%)$ of all $\mathrm{NMHC}$ and $\mathrm{CO}$ emissions occur in the first few minutes of FTP-75 while the converter is warming up [Laing, 1994]. Decreasing these "cold-start" emissions is seen as key to meeting ULEV and other future regulations.

Several approaches have been developed over the past five years for reducing cold-start emissions.

Electrically heated and fuel-fired converters attempt to rapidly heat the converter at the beginning of a trip. They have been shown to reduce the warmup time from two minutes to 10 to 20 seconds, reducing $\mathrm{CO}$ and NMHC emissions by up to $70 \%$ [Pfalzgraf, et al., 1995]. Hydrocarbon traps attempt to capture NMHC until the converter is hot [Burk, et al., 1995]. Primary development issues for these approaches involve system cost, complexity, and durability.

Another approach is to move the converter upstream, as close to the engine manifold as possible. Close-coupled converters can reach operating temperature in under a minute, but special catalyst washcoat techniques must be used to ensure loading durability at the higher exhaust temperatures. Also, care must be taken to keep unwanted heat from the converter from flowing into the engine or passenger compartments. Despite these issues, several automakers are using or are planning to use closecoupled converters. Honda recently announced achieving ULEV standards on a Civic using this approach (and advanced engine control). Although close-coupled converters may be sufficient for some efficient four-cylinder cars (the Civic uses a 79 kW, 106 bhp engine), larger cars are likely to require additional measures. 


\section{CATALYTIC CONVERTER THERMAL MANAGEMENT}

Recently there has been an effort to reduce coldstart emissions by keeping the converter hot between trips. Several automakers and EPA have evaluated adding conventional insulation to the catalytic converter [Hartsock, et al., 1994]. With fibrous refractory insulation, a converter can be kept above its operating temperature for one to two hours (versus 25 minutes for an uninsulated converter). FTP-75 cycles run one hour following a previous cycle had $80 \%$ lower NMHC emissions [Koupal, 1995].

Unfortunately, the FTP-75 test procedure requires a 12- to 36-hour cold soak between the prep cycle and measured cycle. If a thermal management system (TMS) could be developed to maintain converter temperature for 24 hours or more, automakers could achieve excellent FTP-75 emissions results. More important, overall automobile emissions could be dramatically reduced. The EPA has estimated that $98 \%$ of trips occur within 24 hours of a previous trip [U.S. EPA, 1993].

Over the past four years, a catalytic converter thermal management system has been developed by the National Renewable Energy Laboratory (NREL), a U.S. Department of Energy national laboratory. The early designs and thermal performance of this TMS are described in two previous SAE papers [Burch, et al., 1995; Burch, et al., 1994] and in a patent [Benson and Potter, 1995]. This TMS (shown in Figure 1) uses vacuum insulation to dramatically reduce heat loss from the converter shell. Metal bellows with thin porous ceramic inserts reduce conduction and radiation heat loss from the inlet and outlet.

In addition to reducing heat loss, the converter uses about $2 \mathrm{~kg}$ of phase-change material (PCM) to significantly boost the heat storage capacity of the converter. As shown in Figure 1, the PCM, typically a eutectic salt or metal alloy, is sealed in an annulus located between the converter monoliths and the vacuum insulation.

To protect the converter from over-heating, the vacuum insulation has a variable thermal conductance feature. This feature is described in detail in an SAE paper [Benson, et al., 1994], and a patent [Benson and Potter, 1994]. By heating a few grams of a metal hydride material containing hydrogen, the pressure of hydrogen gas within the vacuum insulation can be varied between 0.01 and 10 torr. This pressure is at most about $1 \%$ of atmospheric pressure, well below a combustion level. Even this small amount of hydrogen, however, can cause a variation in the thermal conductivity of the vacuum insulation of more than 100:1. The hydride can be actively controlled via an electric resistance heater, or passively controlled by the heat of the converter.

\section{RECENT DESIGN IMPROVEMENTS}

The converter TMS prototype reported in SAE paper 950409 demonstrated good heat retention during bench-top tests at NREL, cooling from $600 \mathrm{C}$ to $300 \mathrm{C}$ in just over 19 hours (see Figure 2). However, the aluminum/silicon PCM used in this prototype (PCM \#1) had too high a melting point (580 C). During FTP testing at Chrysler on a Dodge Neon, the PCM could not be melted during either a standard or an extended prep cycle. Still, after a 23-hour cold soak, the converter was $146 \mathrm{C}$, hot enough to reduce the $\mathrm{CO}$ and $\mathrm{NMHC}$ emissions by $52 \%$ and $29 \%$, to 0.27 and $0.037 \mathrm{~g} / \mathrm{mile}$, respectively (using a $11 \mathrm{~g} / \mathrm{l}, 300 \mathrm{~g} / \mathrm{ft}^{3}$ palladium-only catalyst).

In response to these results, the next TMS converter prototype was designed to use a PCM with a melting point of about $350 \mathrm{C}$ (PCM \#2). Changes were also made to the alternating layers of copper foil and glass paper that provide radiation shielding within the vacuum insulation. The result of these changes is shown in Figure 2. The heat retention time (time from $600 \mathrm{C}$ to $300 \mathrm{C}$ ) was increased from 19 hours to 24 hours. This figure also shows the importance of combining vacuum insulation ( $\mathrm{VCl}$ ) and $\mathrm{PCM}$, versus using either alone.

The design characteristics of the present TMS converter are shown in Table 1. Prior to emission testing, the converter was aged on an engine dynamometer (Ford 5.6 I, V-8 engine). This process consisted of running the engine at a moderate speed (525 $\mathrm{C}$ exhaust temperature) for 24 hours, roughly equivalent to 4000 miles of durability driving. A "fullyaged" converter would have 20,000 to 50,000 miles of exposure.

\section{Table 1 - Design Characteristics of TMS Converter}

Catalyst Brick (each of 2) Material Cordierite

Diameter $144 \mathrm{~mm}$ Length $\quad 76 \mathrm{~mm}$ Cell Density 62 cells $/ \mathrm{cm}^{2}$

5.7 in. $3.0 \mathrm{in.}$ 400 cells $/ \mathrm{in}^{2}$

PM Loading

Ratio Density

$$
\text { (5:1 Pt:Rh) }
$$
$2.5 \mathrm{~g} / \mathrm{l}$

$70 \mathrm{~g} / \mathrm{ft}^{3}$

Overall Dimensions

$\begin{array}{lll}\text { Length } & 490 \mathrm{~mm} & 19 \mathrm{in} . \\ \text { Diameter } & 216 \mathrm{~mm} & 8.5 \mathrm{in} .\end{array}$




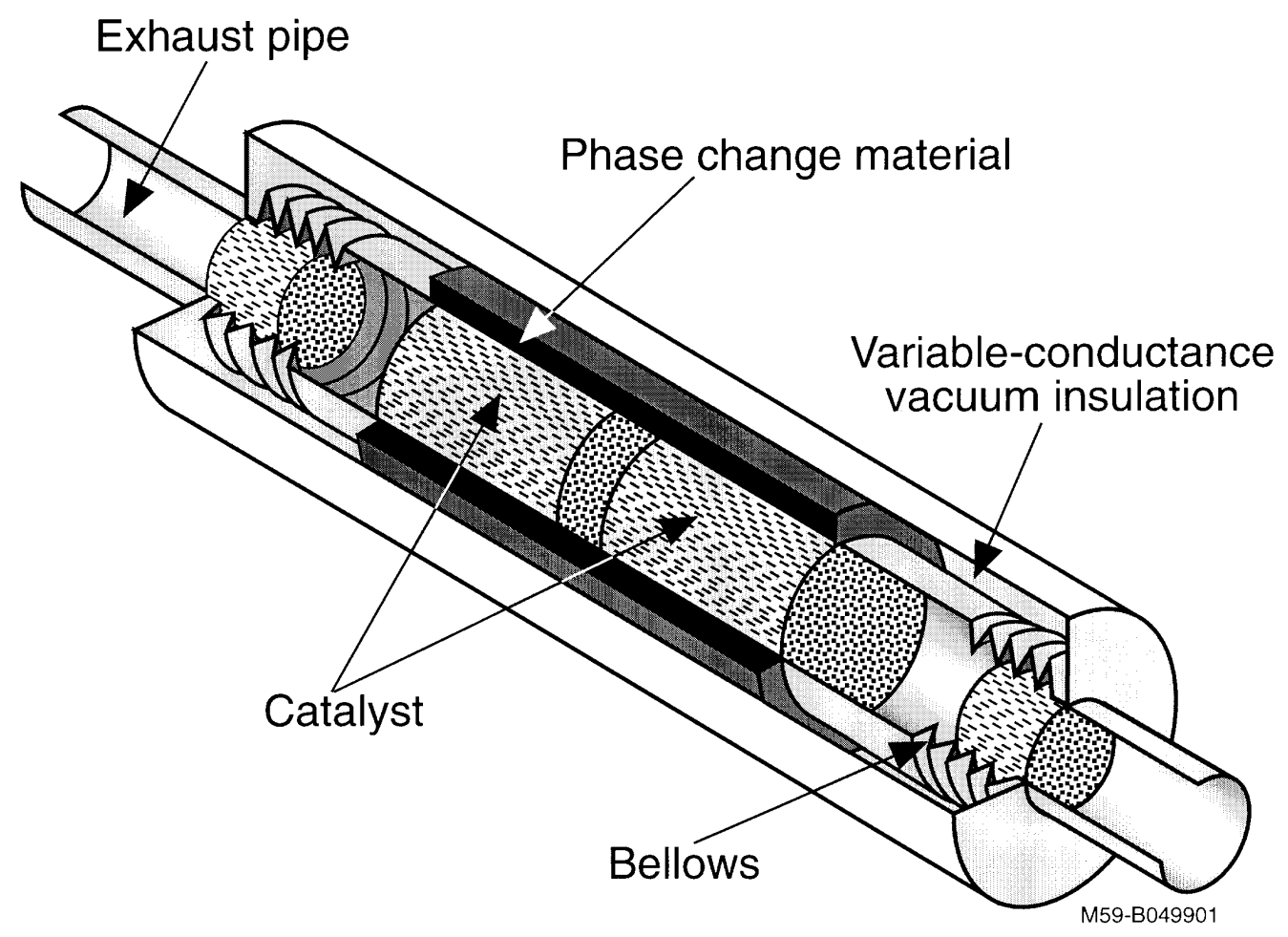

Figure 1 - Drawing of TMS converter

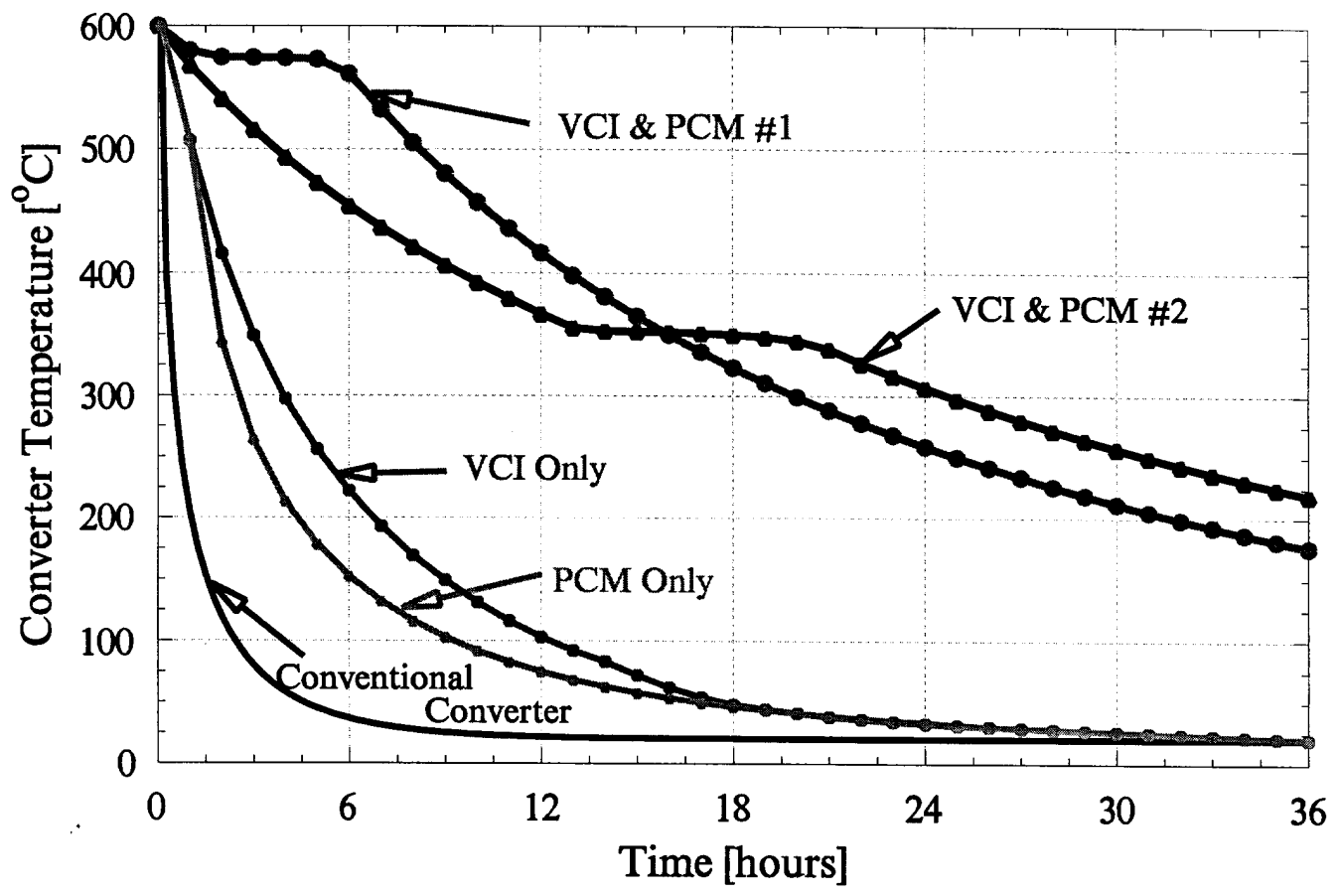

Figure 2 - TMS converter cooldown 
FTP-75 EMISSIONS TESTING

After aging, the TMS converter was installed on a 1993 Ford Taurus FFV (flex-fuel vehicle) with a 3.0 liter V-6 Vulcan engine designed to run on methanol (M85) or gasoline, or any mixture of the two. The optical sensor of the test vehicle was modified to sense a combination of ethanol (E85) and gasoline instead of methanol and gasoline.

The test vehicle was also fitted with a modified exhaust system to accommodate the test article. Due to space constraints and the large diameter of the TMS converter, it was installed about $0.68 \mathrm{~m}$ (17") further downstream than the original (OEM) converters. Fiberglass insulation was used to reduce the heat loss in this additional pipe section (see Figure 3). An air injection port was installed upstream of the test article so that air could be injected into the exhaust stream until the engine went to closed-loop operation.

The TMS converter assembly was tested with both unleaded gasoline (Howell EEE certification fuel) and ethanol (E85). The FTP-75 uses a single Urban Dynamometer Driving Schedule (UDDS) preparation, a 18- to 36-hour ambient soak, and a three-bag FTP cycle during which $\mathrm{HC}, \mathrm{CH}_{4}, \mathrm{CO}$, and $\mathrm{NO}_{x}$ are measured $\left(\mathrm{NMHC}=\mathrm{HC}-\mathrm{CH}_{4}\right)$.

In addition to emissions, temperatures at the following seven locations were monitored: inlet and outlet pipe, center of the front and rear bricks, between the bricks, between the front brick and intumescent mat, and between the mat and the stainless steel wall (rear brick). The pressure drop across the TMS converter was also measured. All emissions tests were performed at Southwest Research Institute.

Starting with the TMS converter at ambient temperature $(25 \mathrm{C})$, at the end of the first prep cycle (a single UDDS), the minimum temperature measured in the converter was $270 \mathrm{C}$, on the steel wall around the rear brick. This indicated that although the exhaust gas was greater than $400 \mathrm{C}$ for the majority of the UDDS, the PCM had not melted. Further examination of the temperature data suggested that the intumescent mats were insulating the PCM from the hot exhaust gas.

An extended prep cycle, consisting of one UDDS and multiple Highway Fuel Economy Test schedules (HFETs), was used to melt the PCM in the TMS converter. Although temperature measurements indicated that the phase change material melted after the first HFET, two HFET cycles were used for tests with gasoline and three HFET cycles for E85 tests. This procedure resulted in minimum converter temperatures of $420 \mathrm{C}$ or higher for all tests, assuring that the phasechange material was fully melted.
Following an extended prep cycle, the car was "cold-soaked" (at $25 \mathrm{C}$ ) for 18, 24, 30, or 36 hours. After each cold soak period, an FTP cycle was performed and emissions measured. Secondary air injection was used for all tests: $2.4 \mathrm{l} / \mathrm{s}(5 \mathrm{cfm})$ for 110 seconds at the beginning of the test (Bag 1) and for 10 seconds following the 10-minute engine-off period of the cycle (Bag 3). Table 2 shows the total FTP emissions for various soak periods for both the gasoline and ethanol fuels.

For the ethanol fuel, exhaust samples were measured for $\mathrm{HC}, \mathrm{CO}, \mathrm{NO}_{x}, \mathrm{CH}_{4}$, carbonyls (aldehydes and ketones), and alcohols. Nonmethane organic gases (NMOG) were estimated using:

$$
\mathrm{NMOG}=(\mathrm{NMHC}+\text { Carbonyls }+ \text { Alcohols }) \times \mathrm{RAF},
$$

where the Reactivity Adjustment Factor, RAF $=0.67$ as reported in SAE 932676 [Kroll, et al., 1993].

As the data in Table 2 indicate, by keeping the converter hot for 24 hours, the TMS substantially reduced emissions. For gasoline, $\mathrm{NMHC}$ and $\mathrm{CO}$ emissions were reduced by $84 \%$ and $91 \%$, respectively.

The improvement with ethanol was even greater, $96 \%$ and $93 \%$, respectively. The California Air Resource Board is discussing the possibility of creating an Equivalent Zero Emission Vehicle standard for conventional vehicles that emit no more pollution than that caused by the electric power generation used to recharge an electric vehicle. Current proposals are roughly $10 \%$ to $20 \%$ of ULEV levels. The emissions for the Ford Taurus FFV using ethanol and a TMS converter are $13 \%, 7 \%$, and $22 \%$ for NMOG, CO, and $\mathrm{NO}$, respectively.

The minimum temperature in the converter at the end of this FTP-75 test was $370 \mathrm{C}$, indicating that the phase change material had remelted. Although further testing is needed, it appears that as little as one FTP-75type drive (11 miles) per day would keep the converter hot (between $230 \mathrm{C}$ and $550 \mathrm{C}$ ) at all times, and emissions very low.

Maintaining the temperature within this range should also decrease thermal stress on the converter during the warmup period. Pressure drop measurements indicate the TMS converter had slightly less pressure drop than the baseline vehicle. This was also seen in a small improvement in fuel economy. 


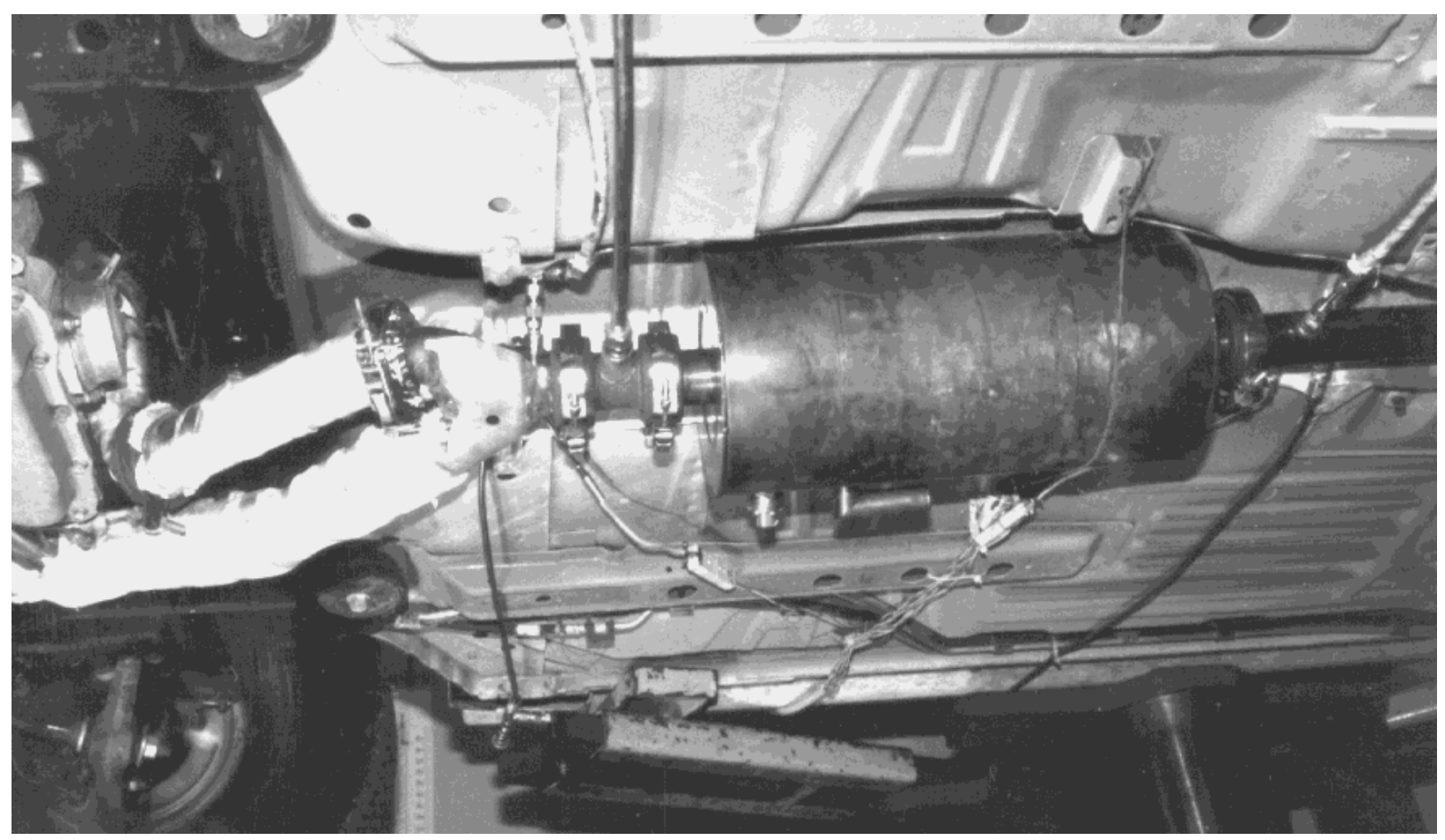

Figure 3 - Photo of TMS converter on Ford Taurus

Table 2 - FTP-75 Emissions for a Ford Taurus FFV with a Thermal Management System (TMS) Converter

\begin{tabular}{|l|c|c|c|c|c|c|c|c|}
\hline & \multicolumn{3}{|c|}{ Unleaded Gasoline } & \multicolumn{4}{c|}{ Ethanol (E85) } & \\
\hline & Baseline & $\begin{array}{c}24-\text {-hour } \\
\text { soak }\end{array}$ & $\begin{array}{c}30 \text {-hour } \\
\text { soak }\end{array}$ & Baseline & $\begin{array}{c}18-h o u r \\
\text { soak }\end{array}$ & $\begin{array}{c}24-h o u r \\
\text { soak }\end{array}$ & $\begin{array}{c}36-\text { hour } \\
\text { soak }\end{array}$ & $\begin{array}{c}\text { CARB } \\
\text { ULEV }\end{array}$ \\
\hline NMHC (g/mi) & 0.194 & 0.031 & 0.025 & $0.115^{\mathrm{a}}$ & $0.006^{\mathrm{a}}$ & $0.005^{\mathrm{a}}$ & $0.037^{\mathrm{a}}$ & - \\
\hline NMOG (g/mi) & - & - & - & $0.210^{\mathrm{b}}$ & $0.006^{\mathrm{b}}$ & $0.005^{\mathrm{b}}$ & $0.040^{\mathrm{b}}$ & 0.040 \\
\hline $\mathrm{CO}(\mathrm{g} / \mathrm{mi})$ & 1.463 & 0.131 & 0.112 & 1.710 & 0.125 & 0.124 & 0.465 & 1.700 \\
\hline $\mathrm{NO}(\mathrm{g} / \mathrm{mi})$ & 0.135 & 0.066 & 0.069 & 0.177 & 0.044 & 0.044 & 0.049 & 0.200 \\
\hline $\begin{array}{l}\text { Converter } \\
\text { Temperature } \\
\text { at Test Start }\end{array}$ & $25 \mathrm{C}$ & $233 \mathrm{C}$ & $189 \mathrm{C}$ & $25 \mathrm{C}$ & $290 \mathrm{C}$ & $235 \mathrm{C}$ & $175 \mathrm{C}$ & - \\
\hline
\end{tabular}

${ }^{a}$ Gasoline derived NMHC = FIDHC - $\left(\mathrm{CH}_{4} \times\right.$ FIDRCH4)-(Ethanol x FIDRETH);

FIDHC - hydrocarbon measured with flame ionization detector calibrated on propane;

FIDRCH4 - FID response factor for methane;

FIDRETH - FID response factor for ethanol

${ }^{\mathrm{b}} \mathrm{NMOG}=(\mathrm{NMHC}+$ Carbonyls + Alcohols $) \times$ RAF. RAF $=0.67$ as reported in SAE 932676 [Kroll, et al., 1993] 


\section{CONCLUSIONS AND FUTURE WORK}

Combining variable-conductance vacuum insulation and phase-change heat storage for catalytic converter thermal management is a relatively new approach to reducing cold-start emissions. Earlier papers reported on the thermal performance and some limited emission reductions, but in the present study, $\mathrm{NMHC}$ and $\mathrm{CO}$ reductions of $84 \%$ to $96 \%$ were achieved using unleaded gasoline and ethanol.

Although these results are extremely encouraging, substantial work remains before this approach can be applied to high-volume automobile production. In order to make this transition from the laboratory to the factory floor, NREL has recently teamed with Benteler Industries, Inc., a major manufacturer of exhaust system components. This lab/industry team is currently developing improved TMS converter designs which begin to address issues of cost, manufacturability, and durability.

To improve the rate of PCM melting, a metal (stainless steel) catalyst "brick" will be used. Metal monoliths are directly brazed to the steel wall, eliminating the thermal resistance of the intumescent mat. Long-term durability studies are being conducted to evaluate the containment of several potential PCMs. Other planned tests include high-temperature shock and vibration durability, emission performance with fullyaged catalysts, and verification of the hydride variableconductance feature at extreme exhaust temperature conditions.

\section{ACKNOWLEDGMENTS}

The authors wish to thank the following sponsors and contributors to the TMS converter development and testing: Kevin Whitney and Patrick Merritt of Southwest Research Institute (emission test support), Gary Wells of Benteler Industries (gasoline testing sponsor), and Brent Bailey of NREL Alternative Fuels Program (ethanol testing sponsor, [Dodge, et al., 1995]).

\section{REFERENCES}

Benson, D.K., and Potter, T.F., 1995

U.S. Patent \#5,477,676, "Method and Apparatus for Thermal Management of Vehicle Exhaust Systems," (December 26, 1995).

Benson, D.K., and Potter, T.F., 1994 U.S. Patent \#5,318,108, "Gas-Controlled Dynamic Vacuum Insulation with Gas Gate," (June 7, 1994).

Benson, D.K., Potter, T.F., and Tracy, C.E., 1994 "Design of a Variable-Conductance Vacuum Insulation," SAE Technical Paper \#940315.
Burch, Potter, Keyser, Brady, and Michaels, 1995 "Reducing Cold-Start Emissions by Catalytic Converter Thermal Management," SAE Technical Paper \#950409.

Burch, S., Keyser, M., Potter, T., Benson, D., 1994 "Thermal Analysis and Testing of a Vacuum Insulated Catalytic Converter," SAE Technical Paper \#941998.

Burk, P., et al., 1995 "Cold Start Hydrocarbon Emissions Control," SAE Technical Paper \#950410.

Dodge, L., et al., 1995 "Development of a Dedicated Ethanol Ultra-Low Emission Vehicle - Phase 2 Report," NREL Technical Paper 425-8195, NTIS \#DE95013145, September 1995.

Graedel, T., et al., 1988 "Ambient Levels of Anthropogenic Emissions and their Atmospheric Transformation Products," in Air Pollution, the Automobile and Public Health, A.Y. Watson, National Academic Press, Washington, pp. 133-160.

Hartsock, D., Stiles, E., Bable, W., Kranig, J., 1994 "Analytical and Experimental Evaluation of a Thermally Insulated Automotive Exhaust System," SAE Technical Paper \#940312.

Koupal, J., 1995

"Controlling Emissions Following Intermediate Soak Periods," SAE Cold Start Emissions TOPTEC, Jan. 12-13, 1995, Golden, CO.

Kroll, M., et al., 1993

"Influence of Fuel Composition on NMOG Emissions and Ozone Forming Potential,' SAE Technical Paper \#932676.

Laing, P.M., 1994 "Development of an Alternator-Powered ElectricallyHeated Catalyst System," SAE Technical Paper \#941042.

Pfalzgraf, B., et al., 1995

"The System Development of Electrically Heated Catalyst (EHC) for the LEV and EU-III Legislation," SAE Technical Paper \#951072.

U.S. Environmental Protection Agency (EPA), 1993 "Federal Test Procedure Review Project: Preliminary Technical Report," EPA 420-R-93-007, May 1993. 